American Journal of Qualitative Research

June 2019, Vol.3 No. 1, pp. 117-135

https://doi.org/10.29333/ajqr/5814

(C) 2019 AJQR. http://www.ajqr.org
AMERICAN

JOURNALOFOUAUTATIVE

ISSN: 2576-2141

\title{
Qualitative Meta-Data Analysis: Perceptions and Experiences of Online Doctoral Students
}

\author{
Patricia Akojie ${ }^{1}$ \\ University of Phoenix \\ Fern Entrekin \\ University of Phoenix \\ Debra Bacon \\ University of Phoenix \\ Therese Kanai \\ University of Phoenix
}

\begin{abstract}
The profiles of online and traditional doctoral students contrast sharply. A traditional doctoral student lives on-campus and pursues the degree in a face to face environment. This meta-data analysis peruses the research findings from primary research studies on online doctoral students. A systematic search of qualitative research articles, that presented the personal perspectives of online doctoral students, was examined to identify common properties in isolated studies. Factors that directly impact the ability of doctoral candidates to be successful in their online doctoral degree program were identified. Positive factors included cohort groups, supportive mentors, and the ability to pursue a doctoral degree. Obstacles faced by doctoral online students included balancing work, family, school, and a sense of isolation. The results of this meta-data analysis will provide higher education with insights into the online doctoral students' perceptions and experiences.
\end{abstract}

KEYWORDS: Adult Learners, Distance Learning, E-Learning, Meta-Data Analysis, Online Education, Virtual Universities, Higher Education

\section{Introduction}

As society realizes the need for highly qualified workforce to be actively working in various career fields, it is imperative for individuals to seek a higher level of education such as that of a doctoral degree. With only about two percent of the overall population possessing a doctoral degree as reported by the United States Census Bureau in 2011 (Spreen, 2013), the need for higher education is critical. Attainment of higher education prior to the online modality caused many individuals seeking this degree an impossible

${ }^{1}$ Corresponding author; Associate Faculty at the University of Phoenix, School of Advanced Studies. Email: paakoj00@yahoo.com 
venture due to the responsibilities of life. Attendance through an online doctoral program of study has opened many doors for those seeking higher education where doors were closed in the past.

Researchers reported a shift in doctoral student population demographics (Bolliger \& Halupa, 2012; Offerman, 2011). Traditionally, doctoral students were male, single, studying full-time and working for a university that would subsidize their tuition as they worked toward a terminal degree (Offerman, 2011). The nontraditional student has become increasingly female, studies part-time, is a working professional, and is self-funded (Kumar, Johnson, \& Hardeman, 2013; Offerman, 2011; Wilder et al., 2017). The shift from traditional to non-traditional has expanded because of advances in technology, changes in workforce needs, and the development of a global economy (Evans \& Green, 2013). Technology has enabled students to work online, pursuing an education to support a desire for professional knowledge and skills (K1lınc, 2017). Workforce needs have changed, and doctoral degrees are in high demand in fields such as education and health (Evans \& Green, 2013). Additionally, the shift to a global based economy requires people to produce new knowledge (English, 2018) and has precipitated the need for an increasing number of educated professionals (Flynn, 2018). Understanding the perceptions and experiences of online doctoral students can assist universities in developing educational practices that enable effective learning (Fedynich, Bradley, \& Bradley, 2015) and ensure doctoral success for non-traditional students (Karkar-Esperat, 2018; Rockinson-Szapkiw, Spaulding, \& Spaulding, 2016). Many educational environments fail to address the multiple conflicts of family, work, and school faced by nontraditional doctoral students (Offerman, 2011). This meta-data analysis identifies some of the advantages of doctoral online learning and obstacles faced by the students.

A similar meta-analysis was conducted by the Department of Education based on studies in online learning, allowing for 50 independent effects (Means, Toyama, Murphy, Bakia, \& Jones, 2010), besides being based on research from 1996-2008, the study was based on online students in grades K-12. The current meta-data analysis will evaluate the experiences and perceptions of online doctoral students. The information provided in this analysis provides a robust body of knowledge on online doctoral learners. The meta-data analysis provides insight for instructors and administrators working with online doctoral students. For students considering obtaining a doctoral degree online, this analysis will help them be better informed as to whether this is a reasonable possibility for their existing lifestyle.

\section{The Context of the Study}

Numbers of online education students have been gaining ground in the decade beginning with 2010. Sloan Consortium reported over 19.5 million enrolled online students in the Fall of 2010 (as cited in Clapp, 2018, p.3). However, the online doctoral student is a new phenomenon (Offerman, 2011; Santovec 2013). There is a lack of clarity and insight related to the obstacles and advantages faced by these new nontraditional doctoral students (Erichsen, Bolliger, \& Halupa, 2014; Koole, 2013). This meta-data analysis of peerreviewed research précises what has been learned about these students and provides future researchers with an integrated body of knowledge on online doctoral students. 
Technology is now a cosmic part of daily life including education. This includes the use of digital tools for academic communication, high-level thinking and peer support among online graduate students at the doctoral level (Labib \& Mostafa, 2015). Studies are interested in how students access materials online and how they "navigate learning networks" (AlDahdouh, 2018). The process of finding resources online is of interest to designers. Therefore, studies have been searching for better ways of presenting resources to online students. In a 2016 qualitative study, nonresidential student from two regional universities reported that their online courses seemed mechanical in nature and that they developed fewer bonds and relationships with their course mates as a result (Mays, 2016). In lieu of introducing human factor into online courses, hybrid course delivery has been suggested to increase comprehension of course content (McGowan, 2019) as well as promote active learning (O’Rourke, Main, \& Cooper, 2014; Rais-Rohani \& Walters, 2014).

Online doctoral students use social media to keep contact with supervisors and peers (Crosta, Edwards, Wang, Reis-Jorge, Mudaliar, 2018). A cohort of doctoral students in a study, perceived that social media had no significant impact on their academic success (Wandera, James-Waldon, Bromley, \& Henry (2016). However, social media did provide students with avenues to share resources and ideas. The social media tools used include Skype (Xiangming, \& Song, 2018), Youtube (Patterson, 2018), GoogleDocs (Aucoin, 2014), WhatsApp (Saw, Abbott, Donaghey, \& McDonald, 2013), and Wikis (Abdelmalak (2015). Rohr and Costello (2015) also found that Twitter is a quick and efficient way students feel connected to their classmates and the course material.

Investigating ways of establishing connections within online platform has been the impetus behind many research studies that have investigated sense of community in online courses (Lewis, McVay-Dyche, \& Chen, 2015; Terosky \& Heasley, 2015; Tarman, 2018; Tarman \& Dev, 2018). Researchers have found that online learners are more likely to be female, older, married, and have other obligations such as working full time or raising a family (Waldis, Conway, \& Hachey, 2016). Students in online courses often narrated feeling a weaker sense of community in their online course than in their on-ground courses (Said, Kirgis, Verkamp, \& Johnson, 2015). Kennette and Reed (2015) looked at how instructors' presence can help bridge the gap between online and on-campus learning. The study results showed the prominence of having a strong instructor presence in online courses. Not only does instructor presence fuel higher levels of sense of community, it also seems to lead to higher performance levels in online courses (Kennette \& Reed, 2015).

Many students are attracted to online learning because of the flexibility associated with taking online courses. Some of the flexibilities include learning at one's own pace (Barbour, Grzebyk, \& Eye, 2014) and easy access to course materials (Hadjianastasis \& Nightingale, 2016; Wilder \& Berry, 2016). Barbour, Grzebyk, \& Eye's (2014) study was a case study of students in High School. This study is limited to doctoral students. There has been research on online doctoral students which focus on student perceptions relative to satisfaction with and anxiety over their online doctoral program (Bolliger \& Halupa, 2012); students' perceptions of online mentoring (Kumar et al., 2013); and how students should be prepared for online doctoral study (Koole, 2013). However, to date, no synthesis of the studies has been presented.

The purpose of this meta-data analysis is to systematically reexamine the research to develop an integrated body of knowledge on the perceptions and experiences of online doctoral students. An analysis of primary research is crucial to understanding the online 
doctoral students' perceptions. The doctoral student's areas of concern and perceived areas of advantages are unique for distance educators, so universities can adopt practices that ensure doctoral students' success (Evans \& Green, 2013). Online programs "recognize the special challenges faced by these older students" (Offerman, 2011, p.29). This meta-data analysis provides an integrated body of knowledge on the concerns, and perceived benefits of pursing a doctoral program online. The analysis provides information to online doctoral students, administrators, teachers, and others involved in the education process.

\section{Research Question}

The experiences of online doctoral students are complicated on many levels both personal and professional (Gardner \& Gopaul, 2012). The meta-data analysis evaluates data from qualitative research. Analysis of the studies provides aggregate data across studies of doctoral students' perception of their online learning experiences. The results will provide better understanding of online doctoral students as well as provide data to develop plans to support this growing higher education population. This study will specifically answer the following question: What are the perceptions and experiences of online doctoral learners?

\section{Methodology}

Important findings from evidence-based studies are being underutilized and qualitative meta-data analysis is a means toward "enhancing the relevance and utility of qualitative research" (Sandelowksi, 2004). Qualitative research is inherently flexible and is used in meta-data analysis to compare the perspectives of participants in isolated studies (Paterson, Thornes, Canam, \& Jillings, 2011). Meta-data analysis, formally analyzes and compares primary data to develop a body of knowledge on a specific phenomenon (Paterson et al., 2011). By comparing the findings of primary research studies, common focus and common themes are identified. This meta-data analysis, extends the knowledge, brings clarity, and understanding of the perceived experiences of online doctoral students. Although attempts to understand the perceptions of online students have been conducted, few attempts to use meta-data analysis are evident (Sandelowski, 2004). This study is guided by Noblit and Hare (1988) approach, a well-known model for meta-data analysis.

A literature review report would limit summarizing prior research. Our intent is to integrate the data from qualitative studies to better understand the personal challenges and positive experiences of online doctoral students. Qualitative meta-data analysis provides understanding on how isolated research studies are connected (Paterson et al., 2011). The purpose of meta-data analysis is to identify and synthesize key themes in primary studies (Paterson et al., 2011; Schreiber, 2012). The goal of this qualitative meta-data analysis is to compare and synthesize evidence-based statements from the perspective of online doctoral students to identify advantages and challenges faced by nontraditional doctoral students. Noblit and Hare (1988) identified seven phases in their meta-ethnography approach: Phase 1: Getting started; Phase 2: Deciding what is relevant; Phase 3: Reading the studies; Phase 4: Determining how studies are related; Phase 5: Translating studies into one another; Phase 6: Synthesizing translations; and Phase 7: Expressing the synthesis. The seven steps provide synthesis of previous qualitative studies and the focus is interpretation of the results of the studies reviewed. 
The validity of the study was ensured by describing the process of the meta-data analysis based on the work on Noblit and Hare (1988). The strength of the synthesis is the multiple case studies reviewed for a broader understanding of the perception and experiences of online doctoral students. This meta-data analysis was limited to studies published in peer reviewed journals between 2011 and 2015, the time frame narrowed the number of studies available for analysis. The analysis is therefore limited to the data available from the five qualitative studies.

Even though articles were narrowly selected to those which best fit the profile of study, the initial studies had some sampling limitations. The sample size of some of the studies were very small, for example Andrew (2012) had only three students. Some studies collected data from one institution or one program within an institution. All five studies were done in three countries: USA, Canada, and Australia. The results are therefore limited to students, disciplines, and the countries of study. It is important to continue to investigate copious ways to understand and support online doctoral students. We suggest expansion that employs other methods.

\section{Qualitative Meta-Data Analysis}

In meta-data analysis, the data is synthesized by comparing research with a common focus (Paterson et al., 2011). After, the initial literature search, more stringent inclusion and exclusion criteria were applied. Noblit and Hare's (1988) steps broaden understanding of the data collected from studies in the literature. Decision was taken during the various stages of analysis to make sure the team met the purpose of the study. From article selection to deciding what is relevant for the analysis. Of the thirty-five articles reviewed, only five focused on the perception of online doctoral learners. The careful assessment of each study adds validity to this meta data analysis. Synthesizing the findings give further meaning to the study.

Phase 1: Getting started. The team started the meta-data analysis by searching for studies that addressed closely identical research questions. Databases such as EBSCOhost, ProQuest, and ERIC were searched for relevant research on online doctoral students. The variables of interest include students' satisfaction, online doctoral students, adult learners, and students' voices within the studies in the literature. The articles are peer-reviewed research studies from a variety of sources. Journals include Assurance in Education, College Student Journal, Contemporary Issues in Education Today, Distance Education, Higher Learning Research Communications, International Journal of Doctoral Studies, International Journal of Information and Communication Technology Education, Journal of Distance Education, Journal of Nursing Education and Practice, Journal of Technology Studies, New Directions for Adult and Continuing Education, Online Learning, Research in Learning Technology, Teaching and Learning, The Qualitative Report, American Journal of Qualitative Research, Turkish Online Journal of Distance Education, Journal of International Students, British Journal of Educational Technology, and Journal of Educators Online.

Thirty-five peer-review journal articles published between 2011 and 2015 focusing on the perceptions of online doctoral learners were identified (see Table 1). Relevant research was selected by using only studies with actual student statements. Studies using author assertions was purposely left out. Non-online doctoral students' studies were also 
eliminated. This is because the experiences and perceptions of online students may be different from other doctoral students. Articles where participants were part-time and in blended programs were eliminated. If the article did not specifically say the students were online, then they do not meet the criteria for inclusion.

Table 1.

Total Search Results

Search Terms

Online Doctoral Students

Non-Traditional Doctoral Students

Part Time Doctoral Students Experiences

Online Doctoral Students Perceptions

Online Doctoral Students Experiences

Total number of articles

\begin{tabular}{l} 
Number of Articles \\
\hline 19 \\
4 \\
8 \\
2 \\
2 \\
35
\end{tabular}

Phase 2: Deciding what is relevant. After the initial literature search, specific criteria for inclusion and exclusion were considered. Dissertations, reviews of research, books, and conference proceedings were eliminated. Research that focused on online doctoral programs from an administrator, program, or instructor perspective were also eliminated. For this meta-data analysis, only qualitative research that included evidencebased statements from participants, as opposed to author assertions were considered. Five studies that answered the research questions and met the criteria of including empirical evidence of the perceptions and experiences of online doctoral students were analyzed.

Phase 3: Reading the studies. Five research studies meeting the relevant criteria were read repeatedly by all members of the team (See Table 2 ).

Table 2.

Study Sample

\begin{tabular}{|c|c|c|c|c|}
\hline Authors & Sample Size & Country & Ethnicity & Discipline \\
\hline Andrew (2012) & 3 & Australia & $\begin{array}{l}2 \text { New Zealand } \\
\text { 1Tasmania }\end{array}$ & $\begin{array}{l}\text { Diverse } \\
\text { disciplines }\end{array}$ \\
\hline $\begin{array}{l}\text { Bolliger \& Halupa } \\
(2012)\end{array}$ & 84 & USA & $61 \%$ Caucasian & $\begin{array}{l}\text { Health and } \\
\text { Education }\end{array}$ \\
\hline Fahlman (2011) & $\begin{array}{l}8 \text { Female } \\
5 \text { Male }\end{array}$ & Canada & Not Provided & Education \\
\hline $\begin{array}{l}\text { Kumar, Johnson, \& } \\
\text { Hardemon (2013) }\end{array}$ & 9 & USA & Not Provided & Not Provided \\
\hline $\begin{array}{lr}\text { Provident, } & \text { Salls, } \\
\text { Dolhi, } & \text { Schreiber, } \\
\text { Matilla, \& } & \text { Eckerl } \\
(2015) & \end{array}$ & 113 & USA & Not Provided & $\begin{array}{l}\text { Occupational } \\
\text { Therapy }\end{array}$ \\
\hline
\end{tabular}


The number of participants in the studies ranged from as little as three to as many as 113 . Participants in all five studies were adults returning to school to obtain either a PhD or EdD degree. Fahlman (2011) reported on the number of males and females. Two studies Andrew (2012) and Bolliger \& Halupa (2012) provided information on the ethnicity of the participants. Three studies were done in the United States, one in Australia, and one in Canada. Bolliger and Halupa (2012) piloted their research instrument before delving into the data collection phase and determined internal reliability at 0.92 (p. 86). Preliminary code definitions were developed, re-examined, and revised in Provident et al.'s (2015) study.

Phase 4: Determining how studies are related. We extracted data from each of the studies. The team identified key metaphors, ideas, and concepts used in each study. The selected five studies explored the perceptions and experiences of doctoral students in varying disciplines. The purpose of the studies ranged from identification of the challenges faced by distance doctoral students to barriers and challenges participants face while pursuing their program. Table 3 shows how the purpose of the study and design are related to each other.

Table 3.

Summary of the Studies

\begin{tabular}{llll}
\hline Author & Purpose & Research Design & Data Collection Method \\
\hline Andrew & Describe the challenges faced by Case Study & Response to five questions \\
(2012) & distance PhD students and & \\
& investigate the skills needed for & \\
mediating distance supervisors & & \\
& and students.
\end{tabular}

$\begin{array}{lll}\text { Bolliger \& } & \begin{array}{l}\text { To determine doctoral students' } \\ \text { technological anxiety and }\end{array} \text { Qualitative method. Three open ended questions } \\ \text { Halupa } & \begin{array}{l}\text { satisfaction with the online } \\ \text { (2012) } \\ \text { environment. }\end{array}\end{array}$

\begin{tabular}{llll}
\hline Author & Purpose & Research Design & Data Collection Method \\
\hline Fahlman & To provide a legacy for future & Qualitative & Storytelling \\
$(2011)$ & doctoral students. & &
\end{tabular}

Kumar, To identify mentoring strategies Johnson, \& used throughout students' online Hardemon doctoral program.

(2013)

Provident, Further the understanding of how Salls, Dolhi, curricular structure contributes to Schreiber,
Phenomenology

Qualitative

Analysis
Semi-structured interviews; 7 participants interviewed by telephone and 2 participants interviewed inperson

Student written capstone project reflections 
Matilla, \& experiences for students at the end

Eckel (2015) of their doctoral program.

Though some studies investigated students' anxiety relative to technology and satisfaction within the online environment (Bolliger \& Halupa 2012). Some studies specifically explored online mentoring strategies (Kumar et al., 2013). Provident et al.'s (2015) study furthers the understanding of how curricular structure contributes to transformative learning experiences for students at the doctoral level. In general, the studies describe the challenges faced by distance doctoral students and investigates the skills needed for mediating distance supervisors and students (Andrew, 2012). Fahlman (2011) hopes his study will provide legacy for future doctoral studies.

Phase 5: Translating studies into one another: In this phase, we gradually started synthesizing the studies by first protecting the individuality of each study. The five studies reviewed used qualitative methodologies. The studies used designs such as Case Study and Phenomenology. One study was mixed methods, Bolliger and Halupa (2012) which used anxiety and satisfaction questionnaire and computed correlation coefficients, however, only the qualitative data was used for this meta-data analysis. The results show that "students with lower technological anxiety scores experienced higher levels of satisfaction in the online environment than learners with higher anxiety scores" (Bolliger \& Halupa, 2012, p. 11). One of the qualitative studies collected data through storytelling (Fahlman, 2011). Andrew's (2012) case study collected thematic data grounded in the literature review of five questions. Kumar et al.'s (2013) study used the phenomenological designs, using face to face and phone interviews. Provident et al.'s (2015) qualitative analysis reviewed and coded students' capstone project reflections.

Phase 6: Synthesizing translations. The next phase is looking for another level of analysis. Looking for common themes and key words that run through the five studies. Common themes in the isolated studies were identified and a cross analysis was completed to identify the key themes as depicted in the findings.

Phase 7: Expressing the Synthesis. Using thematic analysis of the metaphors, ideas, concepts, and key words, we discussed common themes that ran through the five studies in the findings and discussion sections.

\section{Findings}

Participants in the five studies rejoined that online learning was a positive experience with some degree of differences as to what is deemed a positive experience (see Table 4).

\section{Table 4}

Primary Advantages and Obstacles

\begin{tabular}{lll}
\hline Articles & Advantages & Obstacles \\
\hline Andrew (2012) & $\begin{array}{l}\text { Students noted the importance of being } \\
\text { able to stadents identified not having } \\
\text { employment and in their community as for discussion and support with } \\
\text { an advantage. }\end{array}$ & $\begin{array}{l}\text { research, as a challenge. } \\
\text { Place of }\end{array}$
\end{tabular}


Table 4

Primary Advantages and Obstacles

Students found the face to face

meetings important.

Bolliger \& Halupa (2012) Flexibility of the online environment.

Fahlman (2011)

Kumar, Johnson, \& Multiple modes of communication Hardemon (2013)

Provident, Salls, Dolhi, Schreiber, Matilla, \& Eckerl (2015)
Peers provided a safe environment to ask for help and not be judged.

The strong bond and support from the cohort aided their journey.

email, telephone, VOIP, and virtual classroom. Structure provided by the mentor.

Timely, clear feedback from mentors was valued. Peer support helped them stay motivated. Students found it important to make time for their family members and to take breaks when needed.

Students felt the cohort structure was important in providing shared experiences and ongoing opportunities to interact with instructors and other students.

Students commented on new directions for the career and new professional goals because of the program.
Not provided.

Balancing all life commitments. Working with students that might not provide as much support as other students.

Not understanding written feedback.

Finding time to write; time management - handling family and work commitments.

Students were uneasy at the beginning of the program and continued to feel anxiety. However, faculty encouragement supported students and helped them finish the program.

Study participants commented on new directions for their careers and new professional goals as a result of the program (Provident et al., 2015). Being able to work full time and complete a degree was identified as a major advantage (Andrew, 2012; Bolliger \& Halupa, 2012). Fahlman's 2011 study is based on the experiences of a 13-member cohort group enrolled at Athabasca University (AU). The stories of the students provide examples of positive experiences of online doctoral students. The fostering of motivation and support that AU espouses using cohort groups, appears to play a role in these positive experiences. At the beginning of the cohort year, members are brought together for a week-long face to face orientation period. The initial contact and orientation are used to create a "foundation" for the group. It appears that the participation in the cohort group is the focus of the positive experiences of the students. Working collaboratively with teammates kept students going when they began to feel overwhelmed in attempting to maintain a balance between home, work, and school life. Students also said the peer support helped to offset feelings of isolation in the online modality. Being in a cohort program was perceived as an advantage (Provident, et al., 2015). Peer support (Fahlman, 2011; Kumar et al., 2013) and new challenges (Provident et al., 2015) were deemed important and positive experiences. 
Support from dissertation chairs and mentors were helpful. Bolliger and Halupa (2012) conducted a research to understand course anxiety and satisfaction among 84 online health education doctoral students. Participants perceived that their anxiety levels decreased when they got timely feedback and responses to questions from their instructors and mentors (Bolliger \& Halupa, 2012). Kumar et al. (2013) conducted research on a doctoral program at a university that offered classes in an online modality combined with a one-week campus-based session held annually. Twelve students were interviewed who graduated from the program. The students shared that while structure provided by the mentors was helpful, they believed that "dialog initiated and consistently maintained by mentees is as important for a successful online mentoring experience" (Kumar et al., 2013, p. 10).

Participants also expressed concerns that work-life balance was problematic (Fahlman, 2011; Kumar et al; 2013). In Kumar et al.'s (2013) study, all students were working full time and found it hard to find time to work on their proposal and dissertation. Students in the Andrew's (2012) study felt not having access to peers for support was challenging. Additional obstacles included not understanding written feedback (Kumar et al., 2013). In-spite of the obstacles, participants were resilient and stayed with the program to attain their degrees.

Synthesizing the data indicated positive factors such as cohort groups, supportive mentors, multiple mode of communication via technology and the flexibility to pursue a doctoral degree. Obstacles faced by doctoral online students included, difficulty understanding feedback, balancing work, family, school, and a sense of isolation. The positive experiences outweighed the negatives, and therefore increased the likelihood of students continuing their degree in the online modality.

Thematic Analysis. With further analysis, the following themes emerged - peer support, faculty support, technology, loneliness or the human factor, and time management (see Table 5).

\section{Table 5}

Evolving Themes

\begin{tabular}{|c|c|c|c|c|c|}
\hline Themes & $\mathrm{A}$ & B & $\mathrm{F}$ & $\mathrm{K}$ & $P$ \\
\hline Flexibility & $\begin{array}{l}\text { Flexibility of } \\
\text { remaining in } \\
\text { their place of } \\
\text { employment, } \\
\text { family, } \\
\text { communities } \\
\text { and networks }\end{array}$ & $\begin{array}{l}\text { Flexible for } \\
\text { already busy } \\
\text { lives with } \\
\text { work and } \\
\text { family. }\end{array}$ & $\begin{array}{l}\text { Allows to } \\
\text { juggle multiple } \\
\text { roles. } \\
\text { Support from } \\
\text { family helped. }\end{array}$ & $\begin{array}{l}\text { Full time } \\
\text { employees with } \\
\text { families so the } \\
\text { online structure } \\
\text { helps. }\end{array}$ & $\begin{array}{l}\text { Allows to take } \\
\text { the role of } \\
\text { student and full- } \\
\text { time employee. }\end{array}$ \\
\hline Peer Support & $\begin{array}{l}\text { Need Regular } \\
\text { E-community } \\
\text { or online } \\
\text { conferencing }\end{array}$ & $\begin{array}{l}\text { Valued } \\
\text { discussion } \\
\text { with other } \\
\text { students in } \\
\text { similar } \\
\text { situation } \\
\text { valued }\end{array}$ & $\begin{array}{l}\text { Strong support } \\
\text { group within } \\
\text { cohorts The } \\
\text { encouragement } \\
\text { to share in } \\
\text { online } \\
\text { discussions } \\
\text { helped to move } \\
\text { forward in the }\end{array}$ & $\begin{array}{l}\text { Appreciated that } \\
\text { they can share, } \\
\text { and partner with } \\
\text { peers. }\end{array}$ & $\begin{array}{l}\text { Program cohort } \\
\text { structure } \\
\text { provided shared } \\
\text { experiences. } \\
\text { Student cohorts } \\
\text { provided support } \\
\text { to each other } \\
\text { during }\end{array}$ \\
\hline
\end{tabular}


Table 5

Evolving Themes

\begin{tabular}{|c|c|c|c|c|c|}
\hline \multirow[b]{2}{*}{$\begin{array}{l}\text { Faculty } \\
\text { Support }\end{array}$} & \multirow[b]{2}{*}{$\begin{array}{l}\text { Need regular } \\
\text { scheduled e- } \\
\text { meetings. } \\
\text { All students } \\
\text { mentioned the } \\
\text { importance of } \\
\text { meeting with } \\
\text { their academic } \\
\text { supervisor. One } \\
\text { student } \\
\text { mentioned the } \\
\text { importance of } \\
\text { talking to } \\
\text { people in her } \\
\text { workplace. }\end{array}$} & \multirow[b]{2}{*}{$\begin{array}{l}\text { Satisfied } \\
\text { with timely } \\
\text { feedback, } \\
\text { support, and } \\
\text { openness. } \\
\text { Interaction } \\
\text { with } \\
\text { instructor } \\
\text { and peers } \\
\text { was deemed } \\
\text { important. }\end{array}$} & \multicolumn{2}{|l|}{$\begin{array}{l}\text { program with } \\
\text { confidence. }\end{array}$} & \multirow{2}{*}{$\begin{array}{l}\text { challenges and } \\
\text { triumphs, even in } \\
\text { personal matters. } \\
\text { Faculty } \\
\text { encouraged and } \\
\text { supported } \\
\text { students. }\end{array}$} \\
\hline & & & $\begin{array}{l}\text { Academic } \\
\text { support for } \\
\text { writing }\end{array}$ & $\begin{array}{l}\text { Appreciate } \\
\text { receiving timely } \\
\text { feedback and the } \\
\text { variety of online } \\
\text { communication. } \\
\text { Online mentors } \\
\text { provided } \\
\text { support and } \\
\text { guidance in } \\
\text { educational } \\
\text { development } \\
\text { and other } \\
\text { matters. }\end{array}$ & \\
\hline Technology & $\begin{array}{l}\text { Value Online } \\
\text { conferencing } \\
\text { where students } \\
\text { can read, write, } \\
\text { and speak. But } \\
\text { advocated for } \\
\text { E-media such } \\
\text { as skype and } \\
\text { Face to Face } \\
\text { Meetings. } \\
\text { Needs } \\
\text { Electronic } \\
\text { resources on } \\
\text { both } \\
\text { institutional } \\
\text { and discipline } \\
\text { support level. }\end{array}$ & $\begin{array}{l}\text { High } \\
\text { technology } \\
\text { anxiety at } \\
\text { the } \\
\text { beginning of } \\
\text { the program } \\
\text { which } \\
\text { become } \\
\text { Low to } \\
\text { moderate } \\
\text { anxiety with } \\
\text { technology } \\
\text { at the end. }\end{array}$ & NP & $\begin{array}{l}\text { Valued the use } \\
\text { of multiple } \\
\text { technologies and } \\
\text { media such as } \\
\text { emails, } \\
\text { telephones, } \\
\text { skype, } \\
\text { Elluminate, } \\
\text { screen sharing, } \\
\text { CrossLoop etc. } \\
\text { Appreciated } \\
\text { resources links } \\
\text { provided by } \\
\text { mentors }\end{array}$ & NP \\
\hline $\begin{array}{l}\text { Loneliness - } \\
\text { The Human } \\
\text { Factor }\end{array}$ & $\begin{array}{l}\text { Loneliness at } \\
\text { the dissertation } \\
\text { writing stage - } \\
\text { No access to } \\
\text { community of } \\
\text { Scholars. }\end{array}$ & $\begin{array}{l}\text { More } \\
\text { interaction } \\
\text { to get to } \\
\text { know peers } \\
\text { better }\end{array}$ & $\begin{array}{l}\text { Lonely nights } \\
\text { in front of a } \\
\text { computer }\end{array}$ & $\begin{array}{l}\text { Implementing } \\
\text { research without } \\
\text { face to face } \\
\text { support with } \\
\text { faculty and peers } \\
\text { was a challenge. } \\
\text { Sometimes they } \\
\text { did not } \\
\text { understand } \\
\text { written feedback } \\
\text { from mentors. }\end{array}$ & $\begin{array}{l}\text { Transformational } \\
\text { learning that } \\
\text { reflected changes } \\
\text { in personal, } \\
\text { cognitive, and } \\
\text { behavioral } \\
\text { development. }\end{array}$ \\
\hline
\end{tabular}


Table 5

Evolving Themes

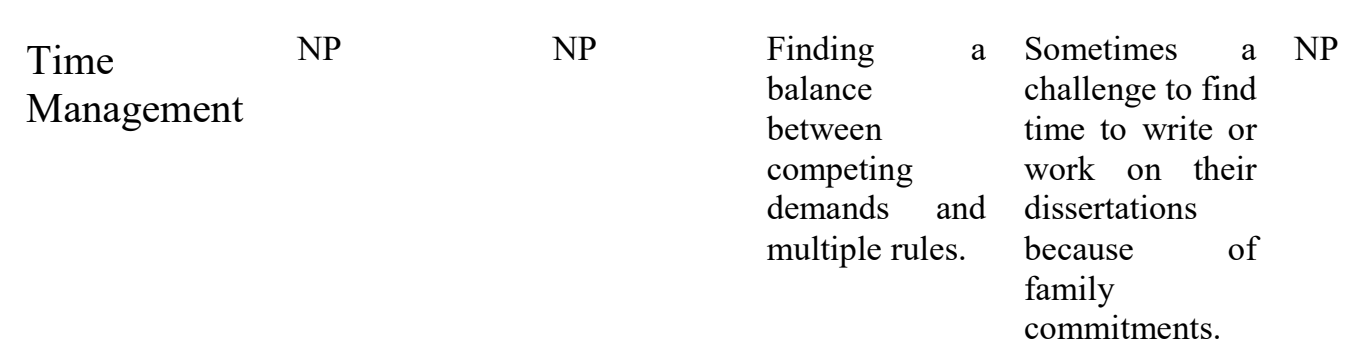

Key: A=Andrew (2012); B=Bolliger \& Halupa (2012); $\mathrm{F}=$ Fahlman (2011); $\mathrm{K}=$ Kumar, Johnson, \& Hardemon (2013); P=Provident, Salls, Dolhi, Schreiber, Matilla, \& Eckel (2015); NP: Not Provided in study results

Flexibility: Flexibility with the online degree is an important theme that ran through the five studies. Participants perceived online learning as flexible, convenient, and conducive to maintaining personal lives (Provident et al., 2015; Bolliger \& Halupa, 2012). Students were positive about being able to stay at their place of employment and in their own community without having to travel or drive to obtain a degree. Being able to work full time and complete a degree was identified as a major advantage. Students also felt it was an advantage to be able to work anytime and anywhere to pursue a doctoral degree. Doctoral candidates make sacrifices in the form of long hours and time away from family; also make compromises to balance all their many roles. They see the online platform making it easier to achieve their degree.

Support Structures: Support takes three forms-support from mentors, classmates, and family. Participants identified the importance of support from dissertation chairs or mentors. Although support from family was mentioned, far more important was support from classmates and faculty. Students in cohort groups identified the cohort as providing positive peer relationships and a "safe" group to go to for help (Provident, et al., 2015). Participants value peer support. They believed peers help them stay motivated (Kumar et al., 2013). Such support is consistent with stories from a cohort of doctoral students who shared that the strong bond and support from other students helped them work together to support each other (Fahlman 2011). As a cohort group, they discovered that some students were good with writing and some with APA format. They discovered each other's strength and helped each other using their individual strengths. They also shared with peers how they cope with a wide range of life commitments such as "family, jobs, and social obligations" (Fahlman 2011, p. 6). The stories shared ranged from academic knowledge and laughter to building long lasting friendships. Making time for family and taking breaks when needed helped students in completing doctoral dissertation online (Kumar et al., 2013).

Technology: Attaining their degree require the use of technology. High technology anxiety at the beginning of the program became low to moderate technology anxiety at the end (Bolliger \& Halupa, 2012). Students felt multiple modes of communication, email, telephone, virtual classrooms, were important to their program (Andrew, 2012 and Kumar et al., 2013). Social media avenues were also advocated such 
as Skype (Andrew, 2012 and Kumar et al., 2013), Elluminate, screen sharing, and CrossLoop (Kumar et al., 2013). Participants advocated for more online resource links

Loneliness -The Human Factor: Being alone especially during the dissertation writing stage was problematic for participants in Andrew's (2012) study. They advocated for e-media such as skype and face to face meetings to access other students (Andrew, 2012). Participants identified technology anxiety as continuing throughout the doctoral program, although some students reported less anxiety as the program progressed (Bolliger \& Halupa, 2012). Students stated face-to-face meetings and faculty encouragement helped to lower anxiety. Timely feedback from mentors also lowered students' anxiety (Bolliger \& Halupa, 2012). Participants expressed that carrying out a doctoral-level research without face-to-face interaction with faculty was a challenge (Kumar et al., 2013). All five studies expressed concern about the dearth of human connections.

Time Management: In some of the studies, participants shared negative perceptions in relationship to their online learning experience much of these stems from the ability of the students to manage their life while trying to attain a terminal degree. Being able to do so in a successful manner requires not only commitment from the learner but also devotion by family members in relationship to the success of the learner. The amount of time, energy, dedication, and commitment to a doctoral degree program of study in the online venue is astronomical in relationship to a daily regimen that more than likely includes caring for family members, working, and schooling. Due to the demands that are put on the time of individual enrolled in an online doctoral program there are never enough hours in the day to accomplish the tasks at hand (Fahlman, 2011). Participants felt their multiple conflicts of family, work, and school were not being recognized by institution and faculty. In one study, all the students were working full time in their professional fields and found it hard to find time to work on their proposal and dissertation (Kumar et al., 2013). The time required for study and learning can ultimately lead to shortchanging oneself in meeting physical and social obligations that are critical for life existence.

\section{Discussion}

Three common themes emerged from the synthesis of the data. These themes, flexibility, peer/faculty support, and loneliness, run across all five studies.

Theme 1: Flexibility. Participants discussed juggling "multiple roles" such as parent, spouse, professional, and student (Fahlman, 2011). Results mirror findings of studies that were not specifically online learners like that of West, Gokalp, Peña, Fischer, \& Gupton (2011), where students found no difference between their professional workdays and studying for their degree program. A concern for finding time and energy for family, job, and school was identified in other studies including Smyth, Houghton, Cooney, \& Casey, (2012) where participants were in a range of blended learning programs. Gardner and Gopaul (2012) reported the frustration of students trying to balance professional work and school related work. Offerman (2011) identified challenges faced by older nontraditional students such as caring for aging parents, ending a marriage, and death of a close family member. He also reported that women doctoral students take on more responsibility for the home and for childcare responsibilities than their male colleagues. Research by Brock and Hawkins (as cited in Santovec, 2013) found a difference between the concerns of men and women in a pre- and post-course semester survey. The survey 
found out that although men were initially concerned about needing support, they settled into a balanced life after the first or second semester. Women, initially concerned about juggling school, job, and family, reported increased concerns in the post course survey. Students relish the flexibility and easy access to course resources (Hadjianastasis \& Nightingale, 2016; Wilder \& Berry, 2016). The downsides include less face-to-face interaction with peers and instructors (Masino, 2015).

Theme 2: Peer and faculty support. Support based on students' perceptions include valuing timely communication and feedback from mentors (Andrew 2012; Bolliger \& Halupa 2012; Kumar et al., 2013), however there was not an overriding method of communication and feedback that stood out. Timely communication between the student and their advisor is a critical predictor for successful completion of the dissertation program (West et al., 2011). The development of classmate social networks was important for supporting students beyond what dissertation chairs, committees, or families could provide (West et al., 2011). These social networks are particularly important in the transitional period between structured core courses and independent work on the dissertation. Beeson et al. (2019) investigating the sense of community in graduate level distance education programs showed that perceived outside interaction with students, sense of community, and outside interaction with faculty accounted for a significant proportion of the variation in participants' total sense of community scores. The instructor-student relationship is one of the essential elements in the educational service encounter (Schlesinger, Cervera, \& Iniesta, (2015) and considered one of the crucial factors of academic performance (Yeboah \& Smith 2016). In cases where instructors are not readily available, students may get assistance from other students and this helps to build a positive learning climate and sense of community (Toom, 2015). According to Evans and Green (2013), students with a stronger perception of community are more likely to stay enrolled in their program.

The cohort structure used in some of the selected studies (Fahlman, 2011; Kumar et al, 2013; Provident et al., 2015) was found to have the same effect on students in similar studies like those of Gardner \& Gopaul (2012), Santicola (2013), Smyth et al. (2012) and West et al., (2011). These studies also reported that cohort grouping is a positive source of support for students. Similarly, participants in Blankenship \& Gibson's (2016) study showed a resilient sense of community among their cohort and used their cohort to build a professional network of peers. A mentoring program, typically one that includes a cohort group, was found to create a positive experience for online doctoral students (Brill, Balcanoff, Land, Gogarty, \& Turner, 2014). Belonging to a cohort can cut down on confusion that a student may feel relative to learning in the online modality. A dedicated program for mentoring can go a long way in facilitating positive student outcomes. Also, a sequential structure of completing the dissertation could be very helpful.

Theme 3: Loneliness. Lack of community and a sense of isolation, with nobody to talk to about their doctoral program was a challenge. The Human Factor is a two-edge sword. Participants have their family but feel lonely because they were physically detached from their academic support. Students miss peer interaction and regret not having the closer relationships they have with peers and faculty in a face-to-face program (Gardner \& Gopaul, 2012). Many online students depend on support from the people they work with and/or from family members. Research supports that one of the ways to increase students' sense of community is through social interaction using technology (Byrd, 2016; Abdelmalak, 2015; Trespalacious \& Perkins, 2016). Using social media tools facilitated learning goals and assisted students to engage more fully in learning communities to "feel 
less lonely" (Crosta et al., 2018). Human connections within the academic program appear important to online doctoral students.

\section{Conclusion and Recommendations for Future Studies}

This meta-data analysis examined five studies to understand the perceptions and experiences of online doctoral students. The study provided a concise analysis of the studies. Students seemed to share the same concern as on-ground students. They share the same challenges that other online master's degree, continue education students face. Arguably, those students also face the many challenges of studying in the online environment. They too face the balance between work, family, and study. Online doctoral students face the many difficulties that regular full time adult doctoral students returning to graduate school face, such as significant other, children, and other family members. They too like regular doctoral students, despite studying online, desired more practical knowledge than theoretical frameworks. The nontraditional online doctoral students have a slightly different support system from the full time on-campus student. They value interaction with peers and instructors and see them as a very important support system. The human factor was an identifiable missing link. Institutions offering online doctoral programs need to ensure students are receiving the interactive support they need to complete their programs, including how program information are communicated to students (Houdyshell \& Kirk, 2018). To enhance human presence online, studies have found it beneficial to use social media that has a well-defined and significant relationship with students' academic work (Wandera, et al., 2016). The flexibility of taking classes online is appealing and online doctoral learning will continue to gain interest. To maintain interest, decrease time spent in doctoral programs, and increase performance, constant contact between the student and instructor is recommended. Research suggested using social sites like Skype, Youtube, GoogleDoc and WhatsApp, since they appeared to be the most used social media tools (Crosta et al., 2018). Increase integration and usage of variety of technology tools may help reduce frustration with communication.

The limitation outlined previously, the small number of articles analyzed, was a main weakness of this study, which limits the generalizability of the results. One recommendation is that more articles be analyzed that include diverse student population, disciplines, and countries. This study analyzed peer-reviewed qualitative studies from 2011 to 2015 , it is recommended that a follow up study be conducted with wider sampling range. This analysis selected only qualitative studies, to give a richer and more conclusive analysis, a broad spectrum of research methods is recommended. Research regarding online doctoral students requires more attention as more universities are providing online options. Despite, these limitations, the analysis provides an intuition of the areas of concern and perceived advantages of pursing a doctoral program online.

\section{References}

Abdelmalak, M. M. M. (2015). Web 2.0 technologies and building online learning communities: Students' perspectives. Online Learning, 19(2), 87-106.

AlDahdouh, A. A. (2018). Jumping from one resource to another: how do students navigate learning networks? International Journal of Educational Technology in Higher Education, (1), 1-17. doi:10.1186/s41239-018-0126-x 
Andrew, M. (2012). Supervising doctorates at a distance: Three trans-Tasman stories. Quality Assurance in Education, 20(1), 42-53.

Aucoin, R. C. (2014). A study of students' perceptions of the use of Web 2.0 applications in higher education (Unpublished doctoral dissertation). University of British Columbia, Vancouver.

Barbour, M. K., Grezbyk, T. Q., \& Eye, J. (2014). Any time, any place, any pace-really? Examining mobile learning in a virtual school environment. Turkish Online Journal of Distance Education, 15(1), 114-127.

Beeson, E. T., Aideyan, B., O’ Shoney, C., Bowes, D. A., Ansell, K. L., \& Peterson, H. M. (2019). Predicting sense of community among graduate students in a distance learning environment. Universal Journal of Educational Research, 7(3), 746-753. doi:10.13189/ujer.2019.070314

Blankenship, J. C., \& Gibson, R. (2016). Learning alone, together: Closed-cohort structure in an online Journalism and Mass Communication Graduate Program. Journalism and Mass Communication Educator, 71(4), 425-439.

Bolliger, D. U. \& Halupa, C. (2012). Student perceptions of satisfaction and anxiety in an online doctoral program. Distance Education. 33(1), 81-98.

Brill, J. L., Balcanoff, K. K., Land, D., Gogarty, M. M., \& Turner, F. (2014). Best practices in doctoral retention: Mentoring. Higher Learning Research Communications, $4(2), 26-37$.

Byrd, J. C. (2016). Understanding the online doctoral learning experience: Factors that contribute to students' sense of community. Journal of Educators Online, 13(2), 102-135.

Clapp M. (April 2018). Virtual Universities. Virtual Universities: Research Starters Education, 1, 1-6.

Crosta, L., Edwards, A., Wang, R., Reis-Jorge, J., \& Mudaliar, M. (2018). How international online students from a professional doctorate in education are using social media and artificial intelligence tools into the thesis stage? Proceedings of EduLearn18 Conference 2018, (pp. 1461-1469), Palma, Mallorca, Spain.

English, M. (2018). Global Finance. Global Finance -- Research Starters Business, 1, 1-7.

Erichsen, E. A., Bolliger, D. U., \& Halupa, C. (2014). Studies in Higher Education, 39(2), 321-338.

Evans, T., \& Green, R. (2013). Doctorates for professionals through distance education. In M. G. Moore (Ed.), Handbook of Distance Education (3rd ed.), (pp. 654-667). New York, NY: Routledge.

Fahlman, D. (2011). Stories from the first cohort in Doctor of Education in distance education. Journal of Distance Education (Online), 25(1), 1-8.

Fedynich, L., Bradley, K. S., \& Bradley, J. (2015). Graduate students' perceptions of online learning. Research in Higher Education Journal, 27, 1-13.

Flynn, S. I. (2018). Economic growth. Economic Growth - Research Starters Business, 1, $1-7$.

Gardner, S. K. and Gopaul, B. (2012). The part-time doctoral student experience. International Journal of Doctoral Studies, 7, 63-78.

Hadjianastasis, M., \& Nightingale, K. P. (2016). Podcasting in the stem disciplines: The implications of supplementary lecture recording and 'lecture flipping.' FEMS Microbiology Letters, 363(4), 1-4. doi:10.1093/femsle/fnw006 
Houdyshell, M. \& Kirk, P. (2018). Graduate students' perceptions on a professional pathway for academic advisors. American Journal of Qualitative Research, 2 (1), 77-96.

Karkar-Esperat, T. M. (2018). International graduate students' challenges and learning experiences in online classes. Journal of International Students, 8(4), 1722-1735. doi:10.5281/zenodo.1468076

Kennette, L. \& Reed, B. (2015). Instructor presence helps bridge the gap between online and on campus learning. College Quarterly, 18(4), 1-10.

Kilinc, E. (2017). Review of Modernising school governance: Corporate planning and expert handling in state education. New York, NY: Routledge. 172 pp., ISBN9781138787476..Research In Social Sciences And Technology, 2(2). Retrieved from http://ressat.org/index.php/ressat/article/view/327

Koole, M. (2013). Preparing learners for online doctoral study: Readiness App. In J. Herrington, A. Couros \& V. Irvine (Eds.), Proceedings of EdMedia: World Conference on Educational Media and Technology 2013 (pp. 2111-2116). Victoria, Canada: Association for the Advancement of Computing in Education (AACE).

Kumar, S., Johnson, M., \& Hardemon, T. (2013). Dissertations at a distance: Students' perceptions of online mentoring in a doctoral program. Journal of Distance Education (Online), 27(1), 1-11.

Labib, N. M., \& Mostafa, R. H. A. (2015). Determinants of social networks usage in collaborative learning: Evidence from Egypt. Procedia Computer Science, 65, 432441. doi:10.1016/j.procs.2015.09.113

Lewis, K. O., McVay-Dyche, J., \& Chen, H. (2015). Examining sense of community among medical professionals in an online graduate program. Journal of Educators Online, 12(1), 1-29.

Masino, M. (2015). Integration of Blackboard in the online learning environment. Journal of Instructional Pedagogies, 16, 1-10.

Mays, T. (2016). Graduate inquiry: Social capital in online courses. Mid-Western Educational Researcher, 28(2), 162-186.

McGowan, G. M. (2019). A correlational study on components of hybrid course delivery and student success in Introductory Statistics (Unpublished doctoral dissertation). Liberty University. Lynchburg, Virginia.

Means, B., Toyama, Y., Murphy, R., Bakia, M., \& Jones, K. (2010). Evaluation of evidence-based practices in online learning: A meta-analysis and review of online learning studies, Washington DC: US Department of Education, Office of Planning, Evaluation, and Policy Development.

Noblit, G. W. \& Hare, R. D. (1988). Meta-ethnography: Synthesizing qualitative studies. Newbury Park: Sage Publications. doi:10.4135/9781412985000

Offerman, M. (2011). Profile of the non-traditional doctoral degree student. New Directions for Adult and Continuing Education, 2011(129), 21-30. doi:10.1002/ace.397

O'Rourke, J., Main, S., \& Cooper, M. (2014). Student perceptions of online interactive versus traditional lectures; or how I managed not to fall sleep with my eyes open. Journal of Online Learning \& Teaching, 10(3), 405-419.

Patterson, A. N. (2018). YouTube generated video clips as qualitative research data: One researcher's reflections on the process. Qualitative Inquiry, 24(10), 759-767. 
Paterson, B. L., Thorne, S. E. \& Canam, C. (2001). Methods in Nursing Research: Metastudy of qualitative health research. Thousand Oaks, CA: SAGE Publications.

Provident, I., Salls, J., Dolhi, C., Schreiber, J., Mattila, A., \& Eckel, E. (2015). Design of an online curriculum promoting transformative learning in post professional doctoral students. Online Learning, 19(3), 128-143.

Rais-Rohani, M., \& Walters, A. (2014). Preliminary assessment of the emporium model in a redesigned engineering mechanics course. Advances in Engineering Education, 4(1), 1-19.

Rockinson-Szapkiw, A. J., Spaulding, L. S., \& Spaulding, M. T. (2016). Identifying significant integration and institutional factors that predict online doctoral persistence. The Internet and Higher Education, 31, 101-112. doi:10.1016/j.iheduc.2016.07.003

Rohr, L. \& Costello, J. (2015). Student perceptions of Twitters' effectiveness for assessment in a large enrollment online course. Online Learning, 19(4), 25-36.

Said, H., Kirgis, L., Verkamp, B., \& Johnson, L. (2015). On-line vs. face-to-face delivery of information technology courses: Students' assessments. Journal of Information Technology Education: Research, 14, 297-312.

Sandelowski, M. (2004). Qualitative meta-analysis. In M. S. Lewis-BeckA. Bryman \& T. F. Liao (Eds.), The SAGE encyclopedia of social science research methods (Vol. 3, pp. 892-893). Thousand Oaks, CA: SAGE Publications Ltd. doi:10.4135/9781412950589.n782

Santovec, M. L. (2013). Serving online students' needs can improve retention. Women in Higher Education, 22(12), 23-23.

Santicola, L. (2013). Pressing on: Persistence through A doctoral cohort program in education. Contemporary Issues in Education Research (Online), 6(2), 253-264

Saw, G., Abbott, W., Donaghey, J., \& McDonald, M. (2013). Social media for international students - it's not all about Facebook, Library Management, 34(3), 156-174. doi: $10.1108 / 01435121311310860$

Schlesinger, W., Cervera, A., \& Iniesta, M. Á. (2015). Key elements in building relationships in the higher education services context. Journal of Promotion Management, 21(4), 475-491. doi:10.1080/10496491.2015.1051403

Schreiber, J. B. (2012). Meta-Analysis. In L.M. Given, The SAGE Encyclopedia of Qualitative Methods (Ed.), 267-274. Thousand Oaks, CA: SAGE.

Smyth, S., Houghton, C., Cooney, A. \& Casey, D. (2012). Students' experiences of blended learning across a range of postgraduate programmes. Nurse Education Today, 32(4), 464-468. doi:10.1016/j.nedt.2011.05.014

Spreen, T. L. (2013). Recent college graduates in the U.S. labor force: Data from the current population survey. Monthly Labor Review. 136(2), 3-13.

Tarman, B., \& Dev, S. (2018). Editorial: Learning Transformation through Innovation and Sustainability in Educational Practices. Research in Social Sciences and Technology, 3(1), i-ii. $\quad$ Retrieved from http://ressat.org/index.php/ressat/article/view/363

Tarman, B. (2018). Editorial: 2018 (3)2. Research in Social Sciences and Technology, 3(2), i-ii. Retrieved from http://ressat.org/index.php/ressat/article/view/370

Terosky, A. L. \& Heasley, C. (2015). Supporting online faculty through a sense of community and collegiality. Online Learning, 19(3), 147-161. 
Toom, A. (2015). Students-enthusiasts in online classes: Their contribution to the educational process. IAFOR Journal of Education, 2, 126-140.

Trespalacious, J., \& Perkins, R. (2016). Sense of community, perceived learning, and achievement relationships in an online graduate course. Turkish Online Journal of Distance Education, 17(3), 31-49.

Waldis, C., Conway, K., \& Hachey, A. C. (2016). Assessing readiness for online education Research models for identifying students at risk. Online Learning, 20(3), 97-109.

Wandera, S., James-Waldon, N., Bromley, D., \& Henry, Z. (2016). The influence of social media on collaborative learning in a cohort environment. Interdisciplinary Journal of e-Skills and Lifelong Learning, 12, 123-143.

West, I. J., Gokalp, G., Peña, E. V., Fischer, L., \& Gupton, J. (2011). Exploring effective support practices for doctoral students' degree completion. College Student Journal, 45(2), 310-323.

Wilder, S., \& Berry, L. (2016). Emporium model: The key to content retention in secondary math courses. Journal of Educators Online, 13(2), 53-75.

Wilder, L. K., Sanon, D., Carter, C., \& Lancellot, M. (2017). Narrative Ethnographies of Diverse Faculty in Higher Education:" Moral" Multiculturalism among Competing Worldviews. Journal of Ethnic and Cultural Studies, 4(2), 1-12.

Xiangming, L. \& Song, S. (2018). Mobile technology affordance and its social implications: A case of "Rain Classroom." British Journal of Educational Technology, 49(2), 276-291. doi:10.1111/bjet.12586

Yeboah, A. K., \& Smith, P. (2016). Relationships between minority students online learning experiences and academic performance. Online Learning, 20(4), 135. doi:10.24059/olj.v20i4.577

Manuscript received April 25, 2019

Final revision received May 13, 2019

Accepted May 20, 2019 